\title{
From a subsistence economy to the production of wealth in ancient formative societies: a political economy perspective
}

\section{Marcella Frangipane ${ }^{1}$ iD}

Received: 12 September 2018 / Accepted: 18 September 2018 / Published online: 26 September 2018 (c) Springer Nature Switzerland AG 2018

\section{Introduction}

I wish to address the transformation from a subsistence economy in the earliest sedentary and food-producing societies in the Near East to a surplus- and 'wealth'-producing economy, in the course of a long process running from the seventh to the third millennium BCE, when the first hierarchical and politically-centralised societies emerged in various regions in this vast and interconnected area. I shall analyse this transformation from the perspective of the different strategies of political economy implemented by the emerging leaders in different natural and social environments in the Near East, by looking at the relationship between these strategies, their social and economic functions in terms of benefit for the population, and the process though which a minority appropriated resources, resulting in increasing inequality.

The political and economic prerogatives of the emerging leaders in different early societies and political systems, ranging from chieftainships to Early States, should be considered from a comparative perspective by observing the different degrees of the rulers' capacity to interfere in the basic economic structures and production systems of the population. What emerges from this comparative analysis is that surpluses were produced for various reasons and purposes, and were used in different ways in differing types of societies, depending also on the political and economic role taken on by the elites (Earle 2015; Risch 2016; Bogaard 2017). Furthermore, the concept itself of 'wealth' and its social perception, eschewing all preconceptions conditioned by the contemporary notion of this economic category, varied considerably from one socio-economic context to another.

Since the only documentary evidence we have for these very early periods are the remains of the material culture left behind by extinct communities, I will necessarily

Marcella Frangipane

marcella.frangipane@uniroma1.it; m.frangipane@libero.it

1 Università degli Studi di Roma La Sapienza, Dip. di Scienze dell'Antichità, Facoltà di Lettere e

Filosofia, Rome, Italy 
be referring to the archaeological evidence on which my reconstructive hypotheses are based.

\section{Different types of subsistence economy in the first agricultural societies}

The earliest communities with a fully productive economy, whose food no longer depended on predatory activities (hunting and gathering wild plants) but on crop and livestock production, expanded throughout a wide area of the Near East at the beginning of the seventh millennium BCE, ranging from the northern Mesopotamian steppe-lands (Jezirah) to the Tigris and Euphrates valleys in central-southern Mesopotamia, south-eastern and southern Anatolia, the Levant, and the foothills of the Zagros mountains between Iraq and Iran. But widely differing types of societies became established in these areas in terms of their political and social organisation, and-what is more relevant for the purposes of this paper-with different ways of producing, managing and consuming resources.

All the early village farming communities must have had facilities for storing their agricultural produce because harvesting took place in a very short space of time and they had to guarantee sufficient quantities of food to meet the needs of the population for a whole year. This must have made some kind of programming necessary, and made them aware of the need to obtain greater amounts of foodstuffs than they actually needed for immediate consumption. This produce, retained and stored, has been called by various scholars as 'surplus production', and considered to be an automatic consequence of the emergence of agriculture. But while the underlying idea that the ability to produce more food than what was necessary for immediate consumption came into being with food production itself is certainly true and fundamental (Childe 1950), we need to reflect on the various possible ways of intending and using surpluses, the reasoning behind its production, and its social function. For a distinction must be drawn between the surpluses to be used to guarantee food security for the members of the community or the household, which was probably a general consequence of the entrenchment of the agricultural economy, and the overproduction intentionally generated to be reinvested in production and exchange in other goods. This process of producing in excess of subsistence requirements gradually developed everywhere and was certainly helped by the development of food conservation strategies and methods, which were essential to be able to make full use of surplus output for later use. But the intensity, the types and the uses of the surpluses varied considerably and had different consequences on social formations and general economic strategies.

The archaeological data available to us suggest that it was the collective organisation of production and the use of surpluses, rather than their household management, that drove the increased output for reinvestment in exchange, both internally, between the various social groups forming the community (farmers and the new emerging categories of full- or part-time specialised artisans), and externally, between different villages or communities, thereby fostering the development of increasingly more specialised 'manufacturing' sectors, leading to the emergence of 
increasingly complex and internally differentiated societies. This stimulus to overproduce was driven above all in societies whose leaders were capable of coordinating labour and the circulation of goods, creating new needs and encouraging overproduction by their subordinates to meet their demands which were claimed to be for the benefit of the community, to satisfy public needs, and to please their gods.

To illustrate the different developments and forms of economic growth in different types of early agricultural societies in the Near East, I will cite the examples of the areas of Syro-Iraqi Jezirah (northern Mesopotamia), central-southern Anatolia, and the plainlands of central-southern Mesopotamia.

The seventh and sixth millennia BCE Neolithic communities in Jezirah collectively managed their food resources, as we infer from the presence of large granaries and storerooms in the more extensively excavated villages, which were certainly available to be used either for the whole community or large sections of it, in which the goods were redistributed among the members of the community using administrative practices based on sealing the containers by the people who withdrew food from the stores (Akkermans 1996; Frangipane 2016). Dozens of seal impressions have been found in these storerooms, which were probably kept there for a time as documentary evidence of the transactions performed there. The decision to share the harvested produce may have been due to the fact that some or all the members of the community would be away on a seasonal basis, probably to engage in pastoralism, making it necessary to appoint someone to ensure the safekeeping of the harvest and guarantee fair and regulated access to the stored commodities (Akkermans and Duistermaat 1996). All this formed part of a mixed economy based on agriculture, livestock and hunting, managed by groups dedicated on a seasonal basis to some of these activities, who then put the goods into circulation around the region which was an ecologically varied environment with areas suitable for exploiting different kinds of resources.

In Anatolia, on the other hand, in an environment run through with the valleys and with a plentiful availability of rain, river and lake water, farming communities thrived on domestic food production and consumption (Asouti and Fairbairn 2002). The stores and the working areas were in the houses or courtyards, and the families, whether nuclear or wider households, were also the basic socio-economic units around which the life of the village revolved, as well as the ideological and symbolic sphere: burials were underneath the houses, there were richly decorated domestic shrines or ritual rooms in various buildings or groups of buildings, and a noticeable absence of recognisable public buildings or common areas, while female figurines found in the houses stressed the idea of fertility, hence propitiating the reproduction and proliferation of families (Düring 2006; Hodder and Pels 2010).

In central-southern Mesopotamia, lastly, from the earliest occupations of these lands, there was evidence of a potentially hierarchical social structure, probably based on unequal kinship descent systems (possibly with the institution of the rights of the first-born, for example) which generated basic inequalities, even though they were initially perhaps only social in character, with social and political rank and roles allocated according to the position of the individuals in the socio-kinship structure (Frangipane 2007). In this type of society, the basic units seem to have been large extended families. In the southern Mesopotamian villages there were 
large houses, certainly for extended families, and in the only village that has been extensively excavated, one particular prominent house has been found, standing out in terms of size, architectural features and the materials used (Jasim 1989). Group identity was also symbolically represented by this chief house, as is suggested by the custom of burying a large number of children and infants under its floor.

This social system was consistent with the natural environment with its high productive potential which, while being difficult and precarious, demanded centrally coordinated management to be able to exploit the real potential (Adams 1966). For the territory consisted of wide plainlands suitable for cereal production, vast enough to permit continuously expanding production from the coastal marshlands near the mouths of the two great rivers, the Tigris and the Euphrates, ideal for horticulture and fishing, to the pasture-rich foothills.

It therefore offered a wide variety of different food resources, but it was condemned to remain unstable not only because of the arid climate, but also the very high water table which exposed the soils to the high risk of salinization and flooding, necessitating coordinated land and water management to make it a safe and productive environment.

This southern Mesopotamian social elites quickly took on this task, creating the conditions for rationalising production while providing food security for the people, and increasing appropriating resources and labour for themselves.

\section{The production of surpluses: food security or 'wealth' production}

These different ways of organising production and managing food (households, collective or centralised) in the earliest agricultural societies impacted differently on raising or reducing the motivation to produce surpluses, leading to different economic strategies or social organisational models.

The structure of the production system in Anatolia remained virtually unchanged until the third millennium BCE, mainly with household-based food production and management and a gradual increase in specialised craftsmanship, also mostly household-based, as shown by the linkage found between the remains of workshops and the houses. Elite and high ranking personages emerged in western Anatolia at the end of the fourth millennium and above all in the third millennium BCE, but they seem to have mainly played a social and political role as pre-eminent persons and chiefs of their communities, who concentrated prestige goods and metal items in their residences and in their burials, but there is no evidence that they managed staple commodities such as foodstuffs, or directly interfered in the economic life of the community. Food surpluses were therefore probably still being produced and managed by households (even chiefs' households-Efe 2003), guaranteeing their members food security and, by exchanging their produce, enabling them to meet their daily needs.

The Mesopotamian societies, conversely, both in the north and the south, developed in a significantly different direction and underwent radical changes in the course of the fifth and fourth millennia BCE. In southern Mesopotamia in particular, there is evidence that the emerging elites interfered in the basic production system 
of staples as early as the fifth millennium BCE, accumulating food in temples which was then redistributed to the people on ceremonial or festive occasions. This led to a flow of goods from the periphery to the centre, and from the ordinary people to the residences of the leaders, who also embodied religious authority, legitimising this concentration of goods in the form of gifts offered to the divinities and making them accepted as the fair exchange of goods and services. Productive unevenness of the territory, together with the hierarchal socio-kinship system, thereby laid the foundations of economic inequality, in which those without adequate resources for survival were supported by the social elites in exchange for their labour (Liverani 1998; Pollock 2012; Frangipane 2016, 2018). This system grew and developed further throughout the fourth millennium when these leaders became full-fledged institutionalised rulers. The public sphere expanded becoming increasingly invasive, and in the end, coincided with the interests of the ruling institutions, above all based initially on an ideological consensus, derived from a powerful religious legitimation and probably also thanks to the common perception of the public utility of the central authorities. This is how the rulers began to acquire at least partial control over the means of production, such as land and livestock, and, above all, labour force, which was remunerated with meals and food rations provided in an increasingly routine way. It was therefore in the temple areas that both religious, political, and economic power was exercised, to the point that the different realms closely interfered and ultimately overlapped. In the large public temple complex in the main and largest city in Mesopotamia (the Eanna at Uruk-Warka), hundreds of seal impressions on various supports, and several thousand pictographic tablets have been found, providing the earliest evidence of 'writing' and codified communication for administrative and accounting purposes (Nissen 2015). On these early tablets, the current items transacted were staple goods: land, livestock, agricultural outcome, animal breeding practices and their secondary products, as well as food rations given as remuneration for labour calculated on the basis of the work performance. Artisans and craft products were listed, but not as the object of economic transactions and accounting procedures.

While the collective management of production and consumption in the sixth millennium BCE north-Mesopotamian egalitarian communities was designed to rationalise and enhance the efficiency of subsistence economy output in a varied but not hostile territory, for the benefit of the entire population, the southern centralised and hierarchical system produced increasing social and economic inequalities, consolidating the 'entrepreneurial' role of the early rulers. Surplus food production became crucial to the functioning of such an economic system in an adverse but potentially productive natural environment and was given a massive boost by the prospect of systematic reinvestment in labour as the sole way of appropriately exploiting the acquisition of increasing land areas and head of livestock. The over-production of food could only have been desirable and productive if there were ways to reinvest it quickly, because perishable goods items were not amenable to being stored and conserved for long periods.

It was perhaps the first time that labour began to be "alienated" being ceded to the community leaders (and perhaps also to other more fortunate members of society) in exchange for the resources needed for survival. This marked the beginning 
of "employment" in embryonic form, leading to a radical change in the manner of organising production and in the structure and the very concept of economic and social relations. From that moment onwards in this type of society, it became possible to speak of a "centralised and redistributive" economy (Polanyi et al. 1957), in which the resources were largely concentrated by the political authorities and ploughed back in the form of allocation of rations and support for production, underpinned by powerful ideological and religious legitimation. It was therefore a system in which the ruling elites embodied a nascent form of institutional government that concentrated resources centrally and redistributed them on the principle of rationalising overall efficiency and developing public works and services. It was perhaps the first time that goods could also be viewed as intangibles (labour or services) to be exchanged for tangibles. The leaders then appeared as operating for the benefit of society, while also acting as "private entrepreneurs" competing with other social groups and driving increased production for their benefit, thus gradually widening the social divide and increasing economic inequalities.

In the late fourth millennium BCE Mesopotamian societies the political and economic activities of the dominant classes gradually merged, so that it is possible to detect the beginning of the implementing of an actual "political economy" in the full sense of the term.

\section{4 'Staple finance' and 'wealth finance': different forms and degrees of centralised interference in the basic economy of the population}

In the earliest agricultural societies, both egalitarian and hierarchal, the availability of plentiful food supplies, and therefore "consumables" to ensure their survival, must have constituted the very essence of the concept of "wealth". The economy, based on the production of foodstuffs and related goods, was mainly directed at ensuring food security and the welfare of the population.

The idea of wealth, however, following conceptual categories used in contemporary economics, has often been applied to the "accumulation" of goods, and hence of "durables" to be stored and possibly exchanged for other goods, whose value was generally a function of their rarity value and the resultant difficulty of obtaining them. Levels of "wealth" and its social distribution have therefore tended to be measured in the studies of early societies in terms of the quantities of goods accumulated and stored, whose remains were in fact easily identified by archaeological research. These goods are mainly so-called "luxury" items and materials, especially metal objects, which were not only made of rare raw materials but also involved complex manufacturing processes to extract and work them. Metals were also amenable to be processed and transformed into a variety of different objects (tools, weapons, implements, containers), and measurable blocks of "semi-worked materials" (ingots), that were easy to re-work into items of different shapes and sizes. On account of these properties, metal came to represent and act as a measurement of value, laying the foundations for its later transformation into coinage.

This process of assigning to the metal a value in itself, making it a measure of value and a medium of trade, took a very long time to develop, and at least in the 
early Near Eastern societies it began a long time after the first experiments in the exploitation of this raw material. Leaving aside the two millennia, from the end of the seventh to the end of the fifth millennium BCE, when societies haphazardly tried experimenting with techniques to extract and process different copper ores varying in degrees of difficulty of extraction (from native copper to oxides and carbonates), and produced only a few small ornaments and implements, such as beads and awls, we can begin speaking about metal production in the full sense of the term in the fourth millennium BCE, in the emerging hierarchical societies. It is only in this period that a larger number and a greater variety of objects and types of metals, such as copper, natural copper alloys (obtained by smelting polymetallic ores), silver and lead were produced. However, in the same period, although with the great progress made in technologies and supplies, mainly prestige objects were produced for the elites, community leaders and high-ranking personages, which have been unearthed mainly in the public areas and in the seats of power, where they were probably displayed and flaunted. Weapons, which began to be produced to a very limited degree at the end of the fourth millennium BCE, also fall within the same category to a certain extent. Working tools and implements were much rarer, as were everyday objects, as is also evidenced by the fact that most of the tools and instruments were still made of stone.

Whereas the volume and importance of metal production increased in the latter half of the fourth millennium BCE driven by the demand from the emerging elites and the new leaders, this was more socially- and politically-oriented, rather than being economically motivated, in the narrow sense of the term.

But, if in the formative phases of political power the pursuit of precious goods was mainly an instrument of ostentation and for reinforcing that power, what were the economic strategies of these early social and political elites? What were the goods that most attracted their interest, and how did this interest link up with their political function and the interests of the community as a whole? What was their idea of "wealth"? When, in what socio-economic contexts and to what degree did staple goods come to acquire the value of instruments for investing in and raising production, primary or otherwise?

Polanyi (1944) and later D'Altroy and Earle (1985) draw a distinction between two types of economic policy in the early hierarchical and centralised societies, one based on staple products, and the other on prestige goods and craft items, which they termed "staple finance" and "wealth finance". But were these two systems for financing the political institutions and their representatives diversified and dual aspects of their interference in the production of the population, or were they different and mutually exclusive economic policy choices? And how did these choices relate to a different conception of wealth? Furthermore, to what extent were the political economy choices of the early rulers intended for the common good, and to what extent did they pursue their own interests as individuals, families or as a social "class"? This is a key question, because I consider it to be closely bound up with the issue of the birth of the State as an institution, and the economic function of public institutions.

In the early Near East, in the period in which the first hierarchal societies run by political elites came into being, different models of society emerged, with a different 
type of political and economic government of the community. In Mesopotamia, Egypt, the Levant and Anatolia, different types of political and economic relations emerged between the rulers and their population, involving different degrees of economic centralisation and a different role ascribed to the staple economy and the wealth economy in the leaders' economic policy strategies.

Let us take as examples, on the one hand, the third millennium BCE societies in Western Anatolia, and, on the other hand, the fourth millennium BCE Mesopotamian societies. In these areas, the social and political hierarchies were formed at different times and in dissimilar social and environmental contexts, playing radically different political and economic roles, and variously interfering in the economic life of the population.

\subsection{Political and economic function of the first leaders in Western Anatolian Early Bronze Age}

In Western Anatolia at the end of the fourth and the beginning of the third millennia BCE (the beginning of the Early Bronze Age), high-rank societies were formed of pre-eminent personages who settled in separate and often fortified places (citadels/ acropolises). They probably also undertook political and military tasks (defending the community), but their sphere of action seems to have been restricted to the city and its environs, in a system of peer-polities perhaps competing with one another (the so-called Troy culture). This period also saw a sharp increase in the production of metal objects, mainly concentrated in these elite buildings and obliterated in the burials, accompanied by a corresponding expansion and intensification of trading relations. Yet there was no tangible sign of any interference by high-rank leaders in the population's production systems, let alone in the primary economy. No foodstuff storage, no bowls for distributing meals, no cretulae and seals for administering internal transactions. The only case we have found of an elite citadel with stores of grain (Efe 2003) it seems to have been a food store serving the high-rank families who lived there, without any sign of moving the goods or interacting with the rest of the population. The staple economy still seems to have been essentially domestic in character, as it had been in the previous millennia (Neolithic and early Chalcolithic), while the new products, such as metal objects, were for the purpose of ostentation and to confirm and consolidate the social role of those who were able to use them and flaunt it. The obliteration of the items in the burials represented the economic "destruction" and elimination of the good, removing it from the circulation while at the same time emphasising the prestige of the person who could afford to agree to this obliteration.

So-called "wealth finance" seems to have prevailed in this type of society even though it is difficult to say how far the production and circulation of luxury items was a full-fledged system for financing the elites or simply accumulating precious goods, such as jewellery and weapons, as a right vested in the rank and political role of the leaders/rulers enabling them to use special objects as a distinctive feature, to reinforce their political and social role, and their prerogatives as the representatives and defenders of the community. 


\subsection{The political economy of Early State rulers in fourth millennium Mesopotamia}

In Mesopotamian societies social inequality was established in the earliest phases of occupation of the southern alluvial plain. The first temples at the site of Eridu have provided archaeological evidence of food redistribution (and hence its previous centralisation) from as early as the fifth millennium BCE, probably on a ceremonial basis. These redistribution practices increased considerably as time passed to involve ever more individuals and setting in motion a system of self-perpetuating regeneration. Throughout the fourth millennium, the social and religious status of high-ranking figures legitimised their function of economic coordination, constantly increasing their prestige and, through it, enhancing their ability to improve agricultural outcomes by improving and coordinating the use of technological tools, such as irrigation and water management, and managing the efficient circulation of staple products from different ecological niches by, at least partly, centralising and redistributing them. This system led these high-rank leaders to take advantage of their public role by creating a feedback circuit: Their prestige facilitated the accumulation of staple products (in the form of either tributes or offerings) and probably means of production (high-yield lands and livestock); the accumulated food became essential, and was reinvested in feeding the people who worked for these leaders and put the centralised means of production to good use; ensuring food security in turn brought greater prestige to the rulers and this legitimised the accumulation of more goods and means of production; but this process also led to the impoverishment of an increasing number of individuals and families, who were forced to provide yet more labour in exchange for food; large-scale and regular redistributions of primary products became routine as a way of remunerating labour; the prestige of high-status leaders turned into political and economic power (Earle 2015; Frangipane 2016).

It was perhaps precisely the ability of this political economy to rationalise production and guarantee the circulation of food produced in various ecological niches in an overall difficult environment, that generated consent and enabled the leaders of the community to hoard resources and inputs. This consensus guaranteed political and social stability to a centralised and top-down system, which created increasing inequality.

By the end of the fourth millennium this system had spread to virtually every centre and area of the larger Mesopotamian world, including all the lands gravitating around the Tigris and the Euphrates, from the Persian Gulf to the mountains of south-eastern Anatolia, generating the development of sophisticated administrative systems and the delegation of authority to individuals acting in the name of the authorities, and thereby creating a whole class of functionaries and bureaucrats. For the first time, this gave rise to a complex centrally-controlled circulation of goods and services which constituted an embryonic form of State, the so-called 'Early State'. Huge quantities of seal impressions, hundreds of mass-produced bowls, and monumental public areas in which, as the concentration of these materials reveals, economic transactions between the leaders and the members of the community mainly took place, are the distinctive archaeological features of the society of the socalled Greater Mesopotamia throughout the whole of the fourth millennium BCE. 
The management of the basic and subsistence production system was indeed the linchpin of the political economy implemented by the early Mesopotamian rulers, who thereby exercised control over the lives of the population. They at the same time pursued the benefit of the community, by producing staple goods to be put into circulation and, in general terms, stimulating the production of wealth, and their own profit, by hoarding a significant part of this wealth as real entrepreneurs, to become the strongest social and economic competing groups, able to dominate vast areas of primary production.

We may certainly speak about 'staple finance' in this connection, as a means of sustaining public and private activities by the elites. But what was the part played by the production and circulation of raw materials and artisanal handiwork in the production system of these societies and in the leaders' political economy strategies?

By fostering demand, the central institutions certainly also drove and stimulated the production of new resources and artisanal and so-called "luxury" or "prestige" goods, such as metal objects. But in the fourth millennium BCE they were still being used above all in the elite circles, enhancing and boosting the prestige of those who owned them and thereby performing a mainly social and political, and only to a limited extent, economic function.

The wide-ranging interregional relations established in previous millennia among the regions of Greater Mesopotamia and the expansion of the centralised system all over this wide world in the fifth and fourth millennia BCE certainly fostered the circulation of raw materials from the mountainous regions surrounding Mesopotamia to the plainlands, where they were lacking. But it was not until the mid-third millennium BCE that any kind of planned and organised trade and State intervention is clearly evidenced. This occurred when craft production and the specialisation of labour become fully involved in producing widely-used objects, instruments and tools, giving rise to specialised production sectors.

Urbanisation, which was a typical Mesopotamian feature, also played an important role in this development. The growth of large cities, with the mingling of so many individuals and diverse production components as well as the availability of services and political institutions, made the inhabitants lose autonomy and generated a system stable and potentially irreversible (Algaze 2008).

It was only in the more mature phase of state societies, however, that raw materials, like metals, began to circulate widely to join the production of tools, work implements and everyday objects. Arsenical copper (so common in the fourth millennium) was then replaced by leaded bronze, an alloy using a metal which was much rarer and more difficult to obtain, but more effective for producing higherquality products with a reduced risk to health in the smelting process. The circulation of lead from distant areas such as Afghanistan and eastern Iran made it necessary to set up organised and systematic trade routes to guarantee regular supplies. And it was in the mid-third millennium BCE that long-distance trade began to play a significant role in the economy of many Near Eastern societies. The involvement of state institutions and private individuals varied from case to case, but both of them played a part in these activities, albeit with different tasks and prerogatives (in most cases the State facilitated the work of private individuals in various ways by acting 
as their clients and protecting and ensuring the security of the trade routes) (Adams 2004).

The expansionism of the nascent empires to conquer new lands was probably driven by these economic interests of the State institutions and their direct or indirect participation in wealth production and management.

But it took a long time for them to achieve these new economic goals and acquire this new concept of wealth, by creating a single staple finance and wealth finance circuit. This at any rate originated from the initial control by the early Mesopotamian leaders on the staple economy, the management of food, and the means for producing it.

\section{Concluding remarks}

Wealth finance has been therefore found in mature states with a highly centralised concentration of power, with a territorial base and political institutions exerting a powerful influence on steering the communities' economic strategies, as it occurred in Mesopotamia and Egypt, as well as in the Hittite Anatolia. There were also major differences between the centralised systems and states in terms of the importance of different sectors of the economy and the part played by the public institutions and private individuals in the management of economic activities. ${ }^{1}$ But the one common feature shared by all these systems was the rulers' capacity to lay down a direction for the economy, taking economic policy choices, and fostering economic strategies able to buttress and consolidate their political power (political economy).

But is it possible to talk about wealth finance in the absence of staple finance in the economies of the early states?

In western Anatolia, in the 'Troia culture' sites, where no evidence has been found of interference by the early high-rank chiefs in the basic economy of the population and where there was a concentration of such 'precious' goods as metals in the fortified citadels and the elite buildings, as well as in the burials, there is no indication of any effective intervention by these high-status personages in the system of producing and circulating these goods, which were produced in a domestic environment and by individual artisans working on their own account. The distribution of the workshops and activity areas in the settlements and the lack of any evidence of central storage or control over artisanal work would seem to back up this hypothesis. The accumulation of durable goods in these societies cannot therefore be considered to have been a means of "financing" the activities of the rulers, but rather a way of flaunting their distinctive position by appropriating for themselves the goods which were not available to others, thereby strengthening and demonstrating their

\footnotetext{
1 Whereas the highly top-down hierarchical system in Egyptian society and the absolute power of the Nilotic state probably left little room for private enterprise, Mesopotamia's structured and complex social stratification enabled all the competing members of society to grow, gradually leaving the state with a more political role of mediating between different interests, in which the central institutions and the families representing them were a powerful party.
} 
pre-eminent status. The flaunting of wealth is not always evidence of a real capacity to produce and manage wealth.

As indicated earlier, it does not appear that the trading relations in metals along wide interregional routes in the third millennium Anatolian communities were subject to any kind of central management or interference by paramount chiefs. They probably encouraged this trade acting as "privileged" clients and political leaders who could guarantee security along the trading routes. The frequent finds of weapons in burials that gave the high-rank personages a warlike connotation, and the construction of protection walls around the elite citadels initially, and subsequently around whole settlements, suggest a high tendency to conflict. This must have increased the demand for metal to produce weapons and to exhibit weapons as a status symbol. But the fact that they were frequently obliterated in the burials is, as already mentioned, also a sign that the metal was not perceived as having any particular commercial and economic value.

In third millennium Anatolian societies we cannot speak of staple finance because of the lack of any form of control over labour and the basic economy, but neither do I believe we can speak of wealth finance, because there does not seem to have been any real system for financing the elites through exercising control over commerce and artisanal crafts to produce wealth in the form of durable goods.

Conversely, it was in the early/state and state societies with a highly centralised and redistributive economy based on controlling and managing the production of staple products, that political power coincided with economic power, and the rulers were eventually able to develop the capacity to also take part and interfere in the production of manufactured goods, transforming some of them into cumulative, tradable, and ultimately measurable, wealth.

\section{References}

Adams, R. (1966). The evolution of urban society. Chicago: Aldine Publishing Co.

Adams, R. (2004). Reflections on the early southern Mesopotamian economy. In G. M. Feinman \& L. M. Nicolas (Eds.), Archaeological perspectives on political economies (pp. 41-59). Salt Lake City: The University of Utah Press.

Akkermans, P. M. M. G. (Ed.). (1996). Tell Sabi Abyad. The Late Neolithic Settlement. Leiden: Nederlands Historisch-Archeologisch Instituut te Istanbul.

Akkermans, P. M. M. G., \& Duistermaat, K. (1996). Of storage and nomads. The sealings from the Late Neolithic Sabi Abyad. Paléorient, 22(2), 17-32.

Algaze, G. (2008). Ancient Mesopotamia at the dawn of civilization. the evolution of urban landscape. Chicago: Chicago University Press.

Asouti, E., \& Fairbairn, A. (2002). Subsistence economy in Central Anatolia during the Neolithic: The archaeobotanical evidence. In F. Gérard \& L. Thissen (Eds.), The Neolithic of Central Anatolia (pp. 181-192). Istanbul: Ege Yayinlari.

Bogaard, A. (2017). The archaeology of food surplus. World Archaeology, 49(1), 1-7.

Childe, V. G. (1950). The urban revolution. The Town Planning Review, 21(1), 3-17.

D'Altroy, T. N., \& Earle, T. K. (1985). Staple finance, wealth finance and storage in the Inka political economy. Current Anthropology, 26(2), 187-206.

Düring, B. S. (2006). Constructing Communities. Clustered Neighbourhood Settlements of the Central Anatolian Neolithic, CA. 8500-5500 Cal. BC. Leiden: Nederlands Instituut voor Het Nabije Ooosten. 
Earle, T. (2015). Conclusions: Surplus and the political economy in prehistory. In C. Morehart \& K. De Lucia (Eds.), Surplus: The politics of production and the strategies of everyday life (pp. 307-326). Boulder: University Press of Colorado.

Efe, T. (2003). Küllüoba and the initial stages of urbanism in Western Anatolia. In M. Özdogan, H. Hauptmann, \& N. Basgelen (Eds.), From Villages to Cities, Studies presented to Ufuk Esin (pp. 265-282). Istanbul: Arkeoloji ve Sanat Yayinlari.

Frangipane, M. (2007). Different types of egalitarian societies and the development of inequality in early Mesopotamia. World Archaeology, 39(2), 151-176.

Frangipane, M. (2016). The development of centralised societies in Greater Mesopotamia and the foundation of economic inequality. In H. Meller, H. P. Hahn, R. Jung, \& R. Risch (Eds.), Arm und Reich/ Rich and poor-Competing for resources in prehistoric societies (pp. 469-489). Halle: Tagungen des Landesmuseums für Vorgeschichte Halle, Band 14/II.

Frangipane, M. (2018). Different trajectories in state formation in greater Mesopotamia: A view from Arslantepe (Turkey). Journal of Archaeological Research, 26, 3-63.

Hodder, I., \& Pels, P. (2010). History houses: A new interpretation of architectural elaboration at Çatalhöyük. In I. Hodder (Ed.), Religion in the Emergence of Civilization: Çatalhöyük as a Case Study (pp. 163-186). Cambridge: Cambridge University Press.

Jasim, S. (1989). Structure and function in an 'Ubaid Village'. In E. F. Henrickson \& I. Thuesen (Eds.), Upon this foundation: The Ubaid reconsidered (pp. 79-90). Copenhagen: Carsten Niebuhr Publications.

Liverani, M. (1998). Uruk, la prima città. Roma-Bari: Laterza.

Nissen, H. J. (2015). Urbanization and the technique of communication: The Mesopotamian city of Uruk during the fourth millennium BCE. In N. Yoffee (Ed.), Early cities in comparative perspective. 4000 $B C E-1200$ CE (pp. 113-130). Cambridge: The Cambridge World History, Cambridge University Press.

Polanyi, K. (1944). The great transformation. The political and economic origin of our time. New York: Farrar and Rinehart.

Polanyi, K., Arensberg, C. M., \& Pearson, H. W. (1957). Trade and markets in the early empires. Illinois: Glencoe.

Pollock, S. (2012). Politics of food in early Mesopotamian centralized societies. Origini, 34, 153-168.

Risch, R. (2016). How did wealth turn into surplus profit? From affluence to "scarcity" in prehistoric economies. In H. Meller, H. P. Hahn, R. Jung, \& R. Risch (Eds.), Arm und Reich-Zur Ressourcenverteilung in prähistorischen Gesellschaften/Rich and poor-Competing for resources in prehistoric societies (pp. 33-48). Halle: Tagungen des Landesmuseums für Vorgeschichte Halle, Band 14/I. 